\title{
Types of aggressive victims in bullying situations at secondary school / Tipos de víctimas agresivas en situaciones de bullying en Educación Secundaria
}

\author{
Gonzalo del Moral (a), Cristian Suárez (a), Mª Elena Villarreal (b), and Gonzalo \\ Musitu (a)
}

(a) Universidad Pablo de Olavide; (b) Universidad Autónoma de Nuevo León

\begin{abstract}
The distinction between subtypes of passive and aggressive victims in studies of bullying has been a cornerstone of research in recent decades. However, some aspects of victimization still need further elaboration, such as the differentiation of subtypes of aggressive victims of bullying, the dynamics of the process of victimization, and the perceptions that participants have of their victimized classmates. The objective of this qualitative research is to distinguish between different types of aggressive victims, taking account of the testimonies of secondary school students. Focus groups and in-depth interviews have been conducted with 72 adolescents from the second, third and fourth years of Compulsory Secondary Education and the information has been analysed following the steps proposed by Grounded Theory; a systematic methodology involving the discovery of theory through the analysis of data. The results identify six types of aggressive victims: due to the accumulation of stress, provocative victims, victims through contagion, passive tell- tale victims, academically gifted victims protected by teachers, and finally, displaced aggression victims.
\end{abstract}

Keywords: bullying; aggressive victim; victimization; qualitative methodology

Resumen: La distinción entre víctimas pasivas o sumisas y agresivas o provocativas en los estudios sobre bullying ha sido una piedra angular de la investigación en las últimas décadas. Sin embargo, algunos aspectos siguen necesitando una mayor profundización como la diferenciación de subtipos de víctimas agresivas, la dinámica propia del proceso de victimización así como las percepciones que los participantes tienen de sus compañeros victimizados. El objetivo de esta investigación, de corte cualitativo, es distinguir tipos de víctimas agresivas atendiendo a los testimonios de alumnado de Educación Secundaria. Para ello se realizaron grupos de discusión y entrevistas en profundidad con 72 adolescentes de $2^{\circ}, 3^{\circ}$ y $4^{\circ}$ de ESO y se analizó la información siguiendo los pasos propuestos por la Grounded Theory, una metodología sistemática que implica el descubrimiento de teoría a través del análisis de los datos. Los resultados permiten distinguir seis tipos de víctimas agresivas: por acumulación de estrés, provocativas, por contagio, pasivas delatoras, las víctimas de alto perfil académico protegidas por el profesorado, y por último, las víctimas agresivas por desplazamiento.

Palabras clave: bullying; víctima agresiva; victimización; metodología cualitativa 
Since the pioneering work developed by Olweus at the end of the 1970s, considerable research has been carried out in order to advance existing knowledge on the concept of bullying at school age (Buelga, Cava, \& Musitu, 2012; Cook, Williams, Guerra, Kim, \& Sadek, 2010). Bullying is defined as behaviour intended to harm which may be carried out by one or more persons and which usually occurs repeatedly over a period of time, directed at a victim who finds it difficult to defend themselves in situations in which there is an imbalance of power between the aggressor and the victim (Del Barrio, Martín, Montero, Gutiérrez, \& Ferníndez, 2003; Olweus, 1993). An important premise arises from this definition: being victimized and being the victim of bullying do not necessarily represent the same constructs (Salmivalli \& Peets, 2009).

According to these authors, some studies evaluating victimization show children who have been hit, insulted or rejected involved in symmetrical confrontations, such as fights between children with similar levels of power. Children who are subjected to reactive aggressions by victims of bullying may even appear as victims themselves (i.e. the bullies themselves would appear as victims). There is evidence indicating that any overlaps between 'being a victim of bullying' and 'being victimized' are only moderate (Schäfer, Werner, \& Crick, 2002).

Olweus (1978) and Perry, Kusel, and Perry (1988) argued that victims of school bullying could be categorized into two subtypes: passive and aggressive. This distinction has been subsequently recognized and confirmed by other researchers (Ortega \& del Rey, 2008; Salmivalli \& Nieminen, 2002; Schwartz, 2000). Each type of victim reflects a different way of reacting to bullying and aggression by classmates. Hunter, Mora-Merchán, and Ortega (2004) point out that the way in which the victim sees the violent situation - as a controllable challenge or as an incontrollable threat - impacts on the way they deal with stress in the long term. The way they see these situations has a direct impact on their own levels of stress, especially in terms of the emotional tone experienced by the victims during the episodes of violence. On the one hand, victims may interpret the victimization as a highly traumatic critical experience which, together with their tendency to withdraw, undermines their self-concept leading to depressive symptoms and feelings of solitude; this kind of victim is known as a passive or submissive victim. On the other hand, the victim may develop such negative attitudes towards their peers that, together with their tendency to be impulsive, bring on an aggressive reaction towards their aggressors; this type of victim would be known as a provocative or aggressive victim (Crick, Grotpeter, \& Rockhill, 1999. 
In general, more data is available on passive or submissive victims than on provocative or aggressive types, given the fact that little attention has been paid to the latter types in most of the research carried out on bullying up to now (Cuadrado \& Fernández, 2009). Nevertheless, some authors suggest that not only are there different types of victims (passive or submissive and provocative or aggressive), but also different types of aggression that have different links with victimization. We are referring in particular to reactive aggression (that carried out against another person as a means of defence against an aggression caused by that person) and proactive aggression (that carried out against another person without any apparent aggression having been committed previously that could justify the aggressive behaviour).

The researchers who have distinguished between both types of aggression have demonstrated that the defensive kind is particularly linked to social rejection and victimization, while the proactive kind does not appear to be related or may even indicate a negative relation with victimization. Similar findings have been obtained in both quantitative studies (Camodeca, Goossens, Terwogt, \& Schuengel, 2002; Poulin \& Boivin, 2000; Salmivalli \& Nieminen, 2002) as well as qualitative ones (Schwartz et al., 1998). Unlike reactive aggression, proactive aggression is linked to qualities of leadership and popularity within peer groups (Dodge \& Coie, 1987; Prinstein \& Cillessen, 2003).

Different types of processes may be responsible for the relation between reactive aggression and victimization. Reactive aggressive children may irritate others as a result of their attention problems and impulsivity (Dodge, Lochman, Harnish, Bates, \& Pettit, 1997; Olweus, 1978) and their emotional deregulation may lead to aggressive outbursts (Schwartz, Proctor, \& Chien, 2001) and, therefore, to them being singled out as the object of school bullying. It may also prove gratifying for the bullies to see such children lose their temper and fly out of control. The study carried out by Salmivalli, Lagerspetz, Björkqvist, Kösterman, and Kaukiainen (1996) indicated that pre-adolescents identified counter-attack as a response that was likely to exacerbate the intimidation. Consequently, Kochenderfer-Ladd (2004) and Putallaz and Bierman (2004) found that the seeking of revenge or reactive attacks by those victimized tended to reinforce victimization. Salmivalli and Helteenvuori (2007) found that, more than being a consequence of victimization, reactive aggression preceded victimization in adolescent boys, while this relation was not found among girls.

On the other hand, reactive aggression could also be a consequence of constant victimization (Salmivalli \& Helteenvuori, 2007). Although reactive aggression is often seen as a temperamental reaction, this does not rule out the possibility that other external factors, such as the constant frustration of the bullied individual, may provoke aggressive reactions. On the other hand, reactive aggression is associated with a tendency to be hostile towards others (Dodge \& Coie, 1987; Hubbard, Dodge, Cillessen, Coie, \& Schwartz, 2001), and the rejection and bullying of one's peers may foster a negative view of them (Salmivalli \& Isaacs, 2005). If this is the case, victimization should predict a rise in reactive aggression. From the point of view of practical consequences, this would suggest 
that the reactive aggression of victims could be reduced simply by putting an end to victimization (Salmivalli \& Nieminen, 2002).

Vermande et al. (2007) distinguish between three types of victims: passive, reactive aggressive victims and proactive and reactive aggressive victims. The second type would coincide with what the research has traditionally designated provocative victim, while the third group would traditionally be labelled 'bullyvictim' (Salmivalli \& Peets, 2009).

Increasing our understanding of different types of aggressive victims is essential in order to develop effective intervention strategies. One of the ways of achieving such an increase is through the opinions and experiences of the children and adults involved in the scenarios where bullying occurs (Del Barrio et al., 2003). Smith (1997) argued that 'research on school bullying could make greater use of qualitative methods and case studies: given the overall volume of studies carried out, we know surprisingly little about the relational dynamics of school bullying' (p. 251).

With these premises, this research aims to distinguish between different types of aggressive victims, taking account of the testimonies provided by secondary school students.

\section{Method}

\section{Participants}

According to Andréu (2001), sampling should aim to select the units and sizes that best guarantee the quantity (saturation) and quality (richness) of the information. In this case we have used a purposive and theoretical sampling (Singleton \& Straits, 2004) to select the schools, aiming to ensure that the different contexts and samples would enable a proper comparison of the data, as can be seen in Table 1 (principle of heterogeneity; Valles, 1997).

A total of 72 adolescents took part in the study (40 girls and 32 boys) from four different secondary schools in Western Andalusia (rural/urban; state/ government-subsidized), with different roles within the classroom (aggressors, victims, delegates/mediators, other peers), aged between 12 and 16 years old, and studying in the second, third and fourth years of Compulsory Secondary Education.

\section{Evaluation techniques}

A qualitative methodology has been applied in this study based on the collection of systematic data through two different interview techniques: the first one is a

Table 1. Selection of schools.

\begin{tabular}{lll}
\hline ENVIRONMENT TYPE OF SCHOOL & Urban & Rural \\
\hline State & Two discussion groups & Two discussion groups \\
State-subsidized & Two discussion groups & One discussion group \\
\hline
\end{tabular}


group technique known as the Focus Group or Discussion Group, and the second an individual technique known as in-depth interviews. A semi-structured interview script was used for the discussion groups with 12 questions that explored the following subjects: bully, victim, witnesses, role played by teachers, role played by families and solutions suggested. The in-depth interview script focused on the social and relational dynamics of bullying, exploring the process of victimization, types of aggressor, types of victim and the role played by other people (peers, teachers and parents) with a total of 10 questions.

Seven discussion groups were carried out with eight people on the basis of two selection variables (school area and type of school). All the groups were mixed in terms of sex (male and female), forms (second, third and fourth year of secondary school) and profiles within the class (aggressor, victim, peers). With regard to the in-depth interviews, 16 were carried out (four with aggressors, four with victims, four with witnesses and four with school mediators/class delegates from the second, third and fourth years of secondary school). The composition of a standard discussion group can be seen in Table 2 .

Four different measures have been used to guarantee the rigour and validity of the research, which is of utmost importance in qualitative studies (Relinque, Moral Arroyo, \& González, 2013): first, the data triangulation method, also known as the constant comparative method (Strauss \& Corbin, 1998). This method consists of the systematic comparison of the categories and properties derived from an analysis of the data in different fragments of the same material, between different materials, between different subjects, in different situations and at different points in time, to look for regularities or patterns that enable a category, property or relationship derived from the analysis of the data to be identified as significant.

Second, peer reviews (Creswell \& Miller, 2000) or analyst-to-analyst triangulation (Denzin, 1978), consisting in contrasting the results of each researcher's coding, discarding those in which no agreement is reached. Third, credibility

Table 2. Standard composition of discussion group.

Standard composition of discussion group

\begin{tabular}{|c|c|c|c|}
\hline \multirow[t]{2}{*}{ Eight participants } & Four boys & $\begin{array}{l}\text { Two students from second } \\
\text { form of secondary school } \\
\text { One student from third form } \\
\text { of secondary school } \\
\text { One student from fourth form } \\
\text { of secondary school }\end{array}$ & $\begin{array}{l}\text { Two aggressors } \\
\text { Two victims } \\
\text { Four peers }\end{array}$ \\
\hline & Four girls & $\begin{array}{l}\text { Two students from second } \\
\text { form of secondary school } \\
\text { One student from third form } \\
\text { of secondary school } \\
\text { One student from fourth form } \\
\text { of secondary school }\end{array}$ & $\begin{array}{l}\text { Two aggressors } \\
\text { Two victims } \\
\text { Four peers }\end{array}$ \\
\hline
\end{tabular}


checks or checks of the interested parties (Thomas, 2003): a session for presenting the research data has been carried out at each school, with the participants' contributions being integrated in these sessions and with these contributions being used as feedback in the process of constructing theories. Finally, in the writing phase, the technical literature has helped to extend, validate and refine our knowledge of the subject of this study (theoretical triangulation; Moral, 2006).

\section{Procedure}

The four schools that took part in the study had collaborated on previous occasions in different quantitative studies and the link with these schools was thus used to request them to participate in this study, with the head or study mentor being the contact in all cases. The discussion groups were carried out in the schools, selected and organized by the psycho-pedagogical adviser or the head of the Coexistence Classroom, if one existed, in order to obtain the participation of the best informants possible and to request parental consent for the minors to participate in the study in an expeditious way.

The only requirement was that the variables of sex (male and female) and forms (second, third and fourth years of secondary school) be distributed equally, with the presence of children who had been involved in aggressive episodes between peers (as aggressors, victims or witnesses) as selected by the adviser or mentor in charge of working with the students in the school. Seven different discussion groups were held within spaces provided by the school, with each session lasting an hour, combining one class period with break time. Two adult interviewers, one male and one female, with prior training and with research experience in the field of Social Sciences as well as in the carrying out of interviews of this kind, ran them.

After the first three groups, the idea of carrying out in-depth interviews with the direct protagonists of school violence started to take shape: aggressors, victims, witnesses and mediators/class delegates (the latter would be important figures in the discussion groups in terms of understanding the dynamics of victimization in the class). We requested the consent of two of the schools (those that had specific mediation programmes and training for mediators) in order to collect data related to this new phase and 16 in-depth interviews of 30 minutes were carried out during the minors' break time. In this case, only one interviewer carried out the interviews to facilitate the production of an engaged discussion during the in-depth interview.

All the discussion groups and in-depth interviews were recorded with an Olympus DS-75 recorder, which enabled them to be transcribed and analysed subsequently.

\section{Data analysis}

An adaptation of the approach put forward by Grounded Theory was followed for the data analysis as proposed by Strauss and Corbin (1998). The different phases of the analysis are specified below: 
(1) Preparation of the raw data files: the participants' responses were transcribed and computerized in order for them to be processed later using a qualitative data analysis software programme (the ATLAS.ti 5.0).

(2) First analysis of the raw data: each researcher identified and defined significant fragments of the text and coded them in an intuitive and open way without applying prefixed theoretical assumptions (open coding), taking into account that the codes 'aggressor', 'victim', 'witness', 'family', 'school', 'neighbourhood-community' and 'society' had been introduced into the design previously, and were considered to be deductive theoretical codes. A line-by-line coding process was followed initially, using the ATLAS.ti 5.0 for this process and prioritizing the expressions and terms used directly by the participants of the study (in vivo coding).

(3) Development of the initial categories (axial coding): after completing this process, and in order to validate the study, both researchers compared their system categories. They agreed on 45 categories, representing $90 \%$ of those identified by the researchers. Based on the categories they had agreed on, both researchers worked together reading the data again to reduce the categories and group them together, and to find sub-topics, main and sub categories, and to eliminate redundant categories. This whole process was recorded in theoretical and descriptive notes that were then incorporated into the model resulting from the analysis and into the writing of the results.

(4) The creation of a model of main and sub categories and their properties (selective coding): during this stage, the categories, sub-categories, properties and relations between them that the analysts considered part of the same theoretical framework were reduced and integrated into descriptive or explanatory conceptual networks. Any categories or hypotheses on the relation between these categories that had been noted down during the previous phase were discarded using the constant comparison method, if it was observed that they only functioned in specific situations or lacked sufficient explanatory capacity.

\section{Results}

We will now present the perceptions and theories held by adolescents in relation to provocative or aggressive victims. The composition of the results will be illustrated with some significant literal fragments of the adolescents' speeches, with the coding given to these being as follows: DG (discussion group)/IDI (indepth interview) + number of group or interview + A (girl), O (boy) + number identified by within the group discussion/agr (aggressor), vic (victim), wit (witness) or med (mediator) in the in-depth interviews.

\section{Provocative or aggressive victims}

The results of this study enable a distinction to be made between six different types of aggressive victim identified by the adolescents who participated in the 
study: aggressive victims due to the accumulation of stress, provocative victims, victims through contagion, passive telltale victims, academically gifted victims protected by teachers, and finally, displaced aggression victims.

The first type of victim is defined as an aggressive victim due to the accumulation of stress, a profile we could call 'the pressure cooker', characterized by the reactive aggression of a victim who can no longer tolerate the ridicule, insults, blows or other abusive manifestations of their classmates. While these victims have tended to be passive, suddenly they defend themselves in a reactive way and without asking for the help of third parties (peers or adults).

GD3A4: some children pick on them and they're like little mice and that, and they even take their sandwich off them or hit them, and then one day they've had enough and suddenly they start hitting you or screaming at you and then everyone laughs cause they do it in a really exaggerated way that no-one expects.

In second place, the concept of the provocative victim emerges. These are provocative children who are irritating or argumentative with their classmates and teachers (they prevent the class from being conducted peacefully, insult, make provocative speeches and interrupt the class, even though they end up being the ones who lose out). Also, they are rejected by classmates as well as by the teachers whose classes they disrupt or who they go to when they have been hit or insulted. The problem in this case could be referred to as 'the boy who cried wolf': the teacher tends to believe that the one doing the provoking is the cause of the victimization, meaning that other more passive aspects of the victimization process are given less attention.

GD2A7: No, it is just his way, maybe he does it without meaning to but he still does it. The teacher is explaining something and he starts asking question, just hang on, let the teacher explain, and then the teacher's saying something and he goes and says: 'will you shut up for once', and maybe you say something to him and he turns round and says 'shut it fatty or I'll give you a slap', and he comes and hits me and when I finally give him one back he goes to the head and now he says he can't be bothered to come down, etc.

Thirdly, we identify victims through contagion, who hang around with others who are violent and thus become 'infected', with aggressions, in this case becoming proactive. A boy or girl who changes school and 'starts a new life' is an example of this: they were victimized in their previous school and they now hang around with aggressors in order to compensate for their previous role.

GD1A2: Yes, well there's one in my class who's come from another school and now he messes around with the others and, not as much as the usual bums, but well he gets into trouble as well.

GD1A3: Those who come from other schools tend to make friends with people like that... those who've got to do the year again and stuff like that, because they think that that way they won't pick on them like they did in the other school. 
GD1A 4: But it depends on how they fit in. They might not fit in or the opposite might happen, they might fit in with them and then stuff might happen to them, it depends, if you are new in a place and... The newcomer is always...

In fourth place, passive telltale victims who report their situation to an adult are considered aggressive victims. For adolescents, the fact that a victim decides to tell a parent or teacher is considered to be an indirect and unbalanced aggression (the victim does not defend themself against their aggressor in a direct way, but calls on a punitive figure who has considerable power) for someone who, according to their label as victim, is supposed to stay quiet and not defend themself.

EP4Atest: 6: Joaquín told a teacher because they were in his playground smoking and they were throwing butts at him and he asked them not to throw any more and the kids were 15 or 16 years old and were going to hit him at the gate and everything. What's more, he spent a whole year leaving an hour early.

GD5A2: The worse thing you can do is be a telltale.

GD7O3: If you see they are hitting someone or whatever, you cannot go and tell a teacher because that would make you a telltale.

Fifthly, academically gifted victims protected by teachers are a subtype who share some characteristics with the aggressive victim described above, with a provocative subtype. This particular case relates to bright students who have gained the support and affection of teachers (in contrast to pure provocative victims), but who may provoke their classmates in a subtle way and in particular by using their academic performance and intelligence.

EP11Omed: 6: some students just go looking for trouble, those who are nerds and to top it all whatever they do they're always right as far as the teachers are concerned and are never to blame for anything, and those ones are always at it, provoking others but passing themselves off as the clever ones and since you're the thick one... and then they go crying to the teacher.

Sixthly, we find displaced victims, out of which two subtypes can be identified. The first type is the type that displaces aggression to other non-school contexts, particularly the family context. The frustration generated by being victimized and not defending oneself is related to the possibility of paying for it in other ways. 'How do they know that I'm not going to react in the same way': parents (childto-parent violence) or a scapegoat (that in some cases is also found within the family subsystem, such as younger siblings, although the scapegoat could also be a younger friend).

GD3A4: I know a girl who wasn't liked by the entire school but, knowing that they probably didn't say anything to her, they just ignored her, and she invented things or did something and they were all at it again, and then her sister came along and they were against her as well, because whatever she did she blamed her sister. 
Interviewer: It might even be that since they're against one of your family or your brother and then you arrive and you have to put up with all that...

GD3A4: and they have often tried to hit that girl and then she says that it was not her and that it was her sister, I do not know what, so that the sister ends up with the blame.

A second type of victim with displaced aggression referred to by the group relates to boy and girl bullies who attack as aggressive victims, but this time the victimization is produced in the family context and the displacement is carried out within the school and towards their classmates. In other words, some aggressors could be considered victims in a micro-context and aggressors in others.

GD4A3: I know someone in my class who has been expelled at least seven times.... I don't know them but they keep saying that their mother's thrown a knife at them, that their mother's hit them with a shoe, and then, after all that, all that stuff from home is offloaded on us [...].

Interviewer 2: in other words he brings what happens at home and offloads it at school.

GD4A3: well he can't go and hit his parents.

The different types of aggressive victim identified are summarized in Figure 1

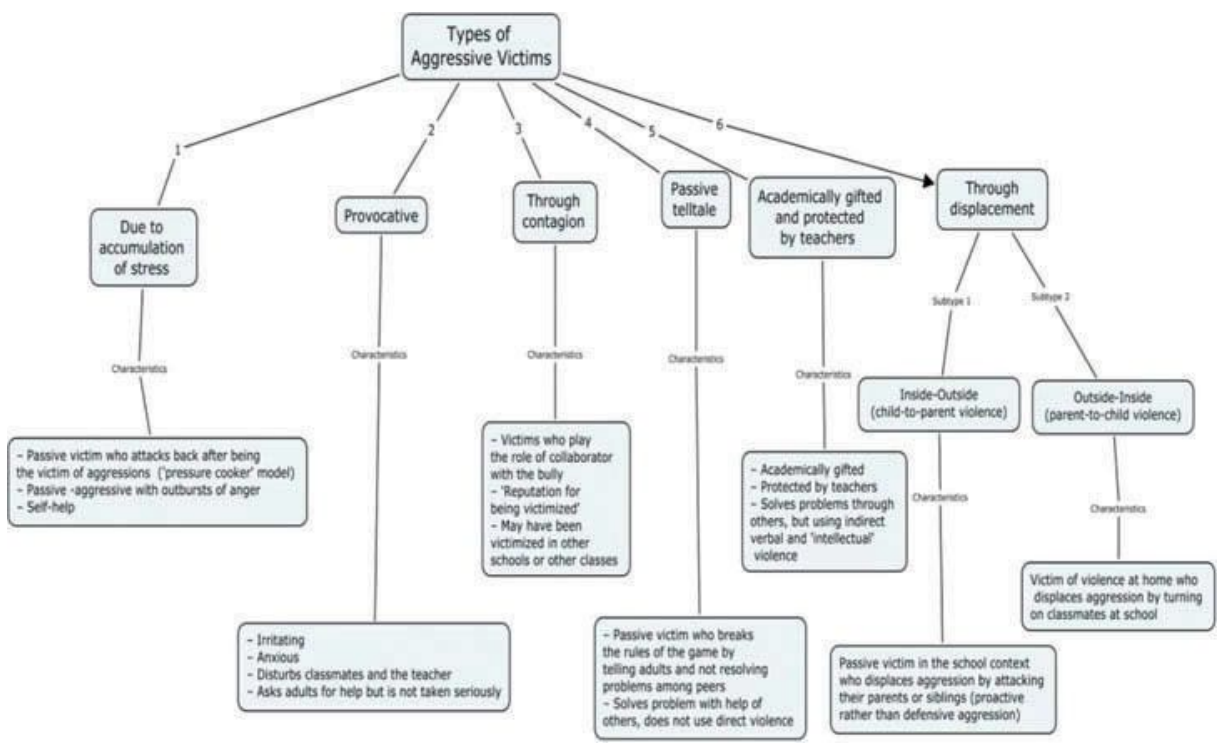

Figure 1. Subtypes of aggressive victims. 


\section{Discussion and conclusions}

This research aimed to distinguish between different types of aggressive victims, taking account the testimonies provided by secondary school students.

In general, we should emphasize that the results of the study go beyond the theory advanced by Vermande et al. (2007), according to which at least two types of aggressive victim can be distinguished: the reactive aggressive victim and the proactive and reactive aggressive victim (or bully-victim). We identify six subtypes of aggressive victims: aggressive victims due to the accumulation of stress, provocative victims, victims through contagion, passive telltale victims, academically gifted victims protected by teachers, and displaced aggression victims.

The first type of victim, defined as a reactive victim due to the accumulation of stress, is in line with the definition established by Salmivalli and Helteenvuori (2007), who suggest that reactive aggression could also be a result of constant victimization. In other words, more than temperamental aspects such as impulsivity, impatience or anxiety, the reasons underlying the transformation of passive victim into reactive one may in fact be external; such as the constant frustration caused by the bullying that ends up producing aggressive reactions.

The consequences of these defensive reactions are contradictory. On the one hand, the research shows results in favour of the relation between reactive aggression and victimization. Salmivalli et al. (1996), for example, pointed out that preadolescents saw counterattacks as a response that would probably exacerbate the intimidation, so that if the victimized child sought revenge or attacked reactively this would probably just reinforce the victimization (KochenderferLadd, 2004; Putallaz \& Bierman, 2004). Nevertheless, one of the solutions suggested by the adolescents and aimed at victims of school bullying is the individual positive strategy known as 'fending for yourself" (del Moral, Suárez, \& Musitu, 2012): speaking out, defending oneself physically and verbally, not being afraid, standing up for oneself and conveying the message that they are not to be messed with. In other words, on the one hand defending oneself may increase the victimization but, according to the adolescents, the victim who 'fends for themself' stops being a victim in a very important way: the imbalance of power with the aggressor decreases and, as a result, they would 'just' be victimized and would stop being victims of bullying (Salmivalli \& Peets, 2009).

The second type of victim would be the provocative victim in line with the descriptions provided by Crick et al. (1999). This kind of victim is characterized by aspects related to impulsivity, anxiety, personality and interpersonal skills. In contrast to other types of victim, adolescents find these types of aggressions justified in such a way that the very definition of victim would be redefined. That is, for adolescents, a provocative aggressive victim deserves what they get due to their constant annoying behaviour. Furthermore, they find no support in the adult world or among their peers, as a result of which the norm in such cases is that they feel alone and unable to find solutions. If we add to this the fact that 
some authors have found the homes of provocative children to be punitive, hostile and with high levels of negligence, over-protection (Bowers, Smith, \& Binney, 1994) and rejection (Veenstra et al., 2005), and with low levels of supervision and affection, we can imagine that the adolescents' cries for attention, attempts to be heard, accepted and loved prove fruitless in the most important development contexts.

Thirdly, aggressive victims through contagion: these victims hang around with violent classmates and imitate their behaviour, attacking proactively. There is widespread agreement that proactive aggression is associated with qualities of leadership and popularity in peer groups (Dodge \& Coie, 1987; Prinstein \& Cillessen, 2003) and that an anxious or timid child who also has friends who is physically weak or rejected by others will be worse placed than another child of similar characteristics with stronger friends who are accepted by others (Hodges, Malone, \& Perry, 1997). The results of our study provide an adolescent theory on the interesting dynamics that result in someone going from being a passive victim to being an aggressive victim through contagion: a change of school or educational level could present an ideal opportunity to stop being victimized or at least to continue being victimized, but with a group of strong peers.

This aspect could be closely linked to the role of those who collaborate with bullies (del Moral et al., 2012; Salmivalli, 2010), since the change in this third type of victim does not entail becoming a bully, but rather in collaborating with the bully, as a result of which certain aspects of the victimization arising from the bullying will continue to be present in their lives, but in a much more controllable, predictable and tolerable way.

Fourthly, we identify the passive telltale victim, who is aggressive in the sense that they do not play the role of the passive victim (not defending oneself, not asking for help), and use strategies for resolving conflicts that are considered illegitimate in the adolescent school culture: asking an adult for help (a teacher or a parent). The adolescents resolve adolescent problems and the situation should not be 'worsened' by introducing adults into the conflict. We have obtained this theory from different schools and with a certain degree of unanimity, not only among aggressors and witnesses, but also as an explanation given by victimized children as to why they did not ask their parents or teachers for help (in one of the schools a girl commented that 'being a telltale was worse than hitting someone unjustly'). This social sanctioning by the adolescents themselves has a damaging effect on victims and any witnesses who could help to solve the situation by reporting it to an adult, as well as hindering the processes of cooperative learning that have shown such positive results in terms of reducing indirect aggressions (León, Gozalo, \& Polo, 2012).

On the other hand, some very interesting ideas have been put forward with regard to displaced aggression victims that enable links to be made between different types of violence and different situations of adolescent development. In the case of 'inside/outside' violence, the following hypothesis is put forward: the accumulated frustration experienced in the school context is expressed in a violent way in the family context against parents or siblings. Some authors have identified 
passive victims' homes as having a more positive family atmosphere than those of bullies and aggressive victims (Bowers et al., 1994). It could be conjectured that aggressions displaced inside the home involve a violent exchange in the case of aggressive victims and bullies, generating two-way situations of violence (Ibabe, 2011), while if a passive victim of bullying starts to be aggressive at home, the violence would be more one-directional (from child to parent).

These data, which link victimization due to bullying with child-to-parent violence, provide new insights in this field and do not coincide with previous studies that highlight the high correlation between being a bully in the school context and being violent with one's parents (Ibabe, Jaureguizar, \& Díaz, 2007; Sempere, Losa, Pérez, Esteve, \& Cerdá, 2005).

Finally, the second subtype of victim due to displacement relates to children who attack in a proactive way in the school context, but who are victimized in their homes. In this case, being victims of abuse, of punitive practices or authoritarian/violent parenting styles is related to a higher probability of being violent at school. Different authors have investigated this particular question and reached the conclusion that, in families where a child is abused, violence is perceived as a way of dissipating anger and frustration, as well as being seen as an acceptable and preferential way of resolving conflicts (Jaffe, Wolfe, \& Wilson, 1990; M cCor d, 19 88). These authors also believe that this could be related to violence in schools (Holt, Buckley, \& Whelan, 2008; Mc Clos key \& Lichter, 2003) or future relationships with partners (Rossman, Hughes, \& Rosenberg, 1999).

In light of these results, we argue that a basic distinction should be drawn between passive victims and aggressive victims, more so than provocative victims as suggested by other authors, since not all of them use provocation or present the traits of impulsivity, impatience or anxiety that are characteristic of provocative victims.

The practical implications of these results are particularly important. Firstly, since the theories presented here come from the experiences and insights provided by adolescents, which are closely linked to the context where the bullying occurs, the simple fact of thinking about their classmates who are being victimized means putting themselves in their place, understanding why they are going through such a painful situation and, at the same time, becoming aware of the role played by each adolescent in relation to school violence among peers. On the other hand, identifying the different types of aggressive victim can help considerably in the design of preventative measures, not only at school level, but also within the classroom, as a tool for teachers to help them be involved and to observe their students in an attempt to support them in their development. The fact that asking adults for help is socially sanctioned in the adolescent school culture should not conflict with attempts to plan measures or provide support in a strategic way. Knowing the characteristics of each type of victim may help in the process of working with the whole group of collaborators, and in exploring their past and present experiences as victims in order to work on empathy; or to explore the family situations of victims in order to find support or even to offer parents help; or in working with whole classes on questioning the implicit norms involved in asking for help. 
The researchers have benefitted immensely from this research, but there are certain points that could improve it further. On the one hand, working only with adolescents from the second to fourth years of secondary school has meant that first year students have been left out. It would have been interesting to have been able to draw on the responses of these students to evaluate victimization at the point in time when they change schools. On the other hand, although the quantity criterion has been fulfilled (theoretical saturation), other respondents, such as teachers and parents, would have helped to complement the data. 


\section{Tipos de víctimas agresivas en situaciones de bullying en Educación Secundaria}

Desde los trabajos pioneros de Olweus a finales de la década de los setenta, han sido muchas las investigaciones encaminadas a profundizar en el conocimiento existente sobre el concepto de bullying en la etapa escolar (Buelga, Cava, y Musitu, 2012; Cook, Williams, Guerra, Kim, y Sadek, 2010). El bullying se define como una conducta dañina e intencional, repetida en el tiempo por una o más personas y dirigida hacia una víctima a la que le resulta difícil defenderse, en situaciones donde hay un desequilibrio de poder entre el agresor y la víctima (Del Barrio, Martín, Montero, Gutiérrez, y Fernández, 2003; Olweus, 1993). Esta definición plantea una importante premisa: ser victimizado y ser víctima de bullying no representan necesariamente constructos idénticos (Salmivalli y Peets, 2009).

Según estas autoras, en ciertos estudios donde se evalúa la victimización aparecen también chicos golpeados, insultados o rechazados implicados en confrontaciones simétricas, como por ejemplo, peleas entre chicos con poder parecido. E incluso podrían aparecer como víctimas los chicos que son objeto de las agresiones reactivas por parte de víctimas de bullying (es decir, aparecería como víctima el propio bully). Hay evidencia de que la superposición entre 'ser víctima de bullying' y 'ser victimizado' es sólo moderada (Schäfer, Werner, y Crick, 2002).

Olweus (1978) y Perry, Kusel y Perry (1988) plantearon que las víctimas de acoso escolar pueden ser categorizados en dos subtipos: pasivo y agresivo. Esta distinción ha sido posteriormente reconocida y confirmada por otros investigadores (Ortega y del Rey, 2008; Salmivalli y Nieminen, 2002; Schwartz, 2000). Cada tipo de víctima refleja una manera distinta de reaccionar frente al acoso y agresión de sus compañeros. Hunter, Mora-Merchán, y Ortega (2004) apuntan a que la valoración que la víctima hace de la situación violenta, como un reto controlable o como una amenaza que no puede ser controlada, ejerce influencia sobre el estrés a largo plazo. Tales valoraciones pueden ejercer una influencia directa en el propio nivel de estrés, especialmente en el tono emocional experimentado por las víctimas durante los episodios de violencia. Por un lado, la víctima puede interpretar la victimización como una experiencia crítica muy traumática que, junto con su tendencia al retraimiento, mine su autoconcepto y desemboque en síntomas depresivos y sentimientos de soledad; esta víctima se conoce con el nombre de víctima pasiva o sumisa; y por otro lado, es posible que la víctima desarrolle actitudes tan negativas hacia sus iguales que, junto con su tendencia a la impulsividad, desencadene una reacción agresiva hacia sus propios 
agresores; ésta sería la víctima provocativa o agresiva (Crick, Grotpeter, y Rockhill, 1999).

En general, existen más datos sobre las víctimas pasivas o sumisas que sobre las provocativas o agresivas, ya que éstas han sido olvidadas en la mayoría de investigaciones sobre bullying realizadas hasta el momento (Cuadrado y Fernández, 2009). Algunos autores sugieren, sin embargo, que no sólo hay diferentes tipos (pasiva o sumisa y provocativa o agresiva) de víctimas, sino también diferentes tipos de agresión que tienen diversas asociaciones con la victimización. Específicamente nos referimos a la agresión reactiva (la realizada contra otra persona como defensa a una agresión por parte de ésta) y a la agresión proactiva (la realizada contra otra persona sin una aparente agresión previa que pudiera justificar la conducta agresiva).

Los investigadores que han hecho la distinción entre ambos tipos de agresión han demostrado que especialmente la defensiva está vinculada al rechazo social y a la victimización, mientras que la proactiva no parece estar relacionada o incluso muestra una relación negativa con la victimización. Hallazgos similares se han obtenido tanto en estudios cuantitativos (Camodeca, Goossens, Terwogt, y Schuengel, 2002; Poulin y Boivin, 2000; Salmivalli y Nieminen, 2002) como cualitativos (Schwartz et al., 1998). A diferencia de la agresión reactiva, la agresión proactiva ha sido asociada con cualidades de liderazgo y popularidad en los grupos de iguales (Dodge y Coie, 1987; Prinstein y Cillessen, 2003).

Diferentes tipos de procesos pueden ser responsables de la relación entre la agresión reactiva y la victimización. Los chicos agresivos reactivos puede ser irritantes para los demás debido a sus problemas de atención e impulsividad (Dodge, Lochman, Harnish, Bates, y Pettit, 1997; Olweus, 1978) y la desregulación emocional puede conducir a arrebatos agresivos (Schwartz, Proctor, y Chien, 2001), y por lo tanto, ser elegidos como objetivos de acoso escolar. Por otra parte, para los bullies podría resultar gratificante conseguir que estos chicos pierdan los nervios y estallen. El estudio de Salmivalli, Lagerspetz, Björkqvist, Österman, y Kaukiainen (1996) indicó que los preadolescentes identi- ficaban el contraataque como una respuesta que era más probable que exacerbara la intimidación. En consecuencia, KochenderferLadd (2004) y Putallaz y Bierman (2004) encontraron que buscar venganza, o agredir reactivamente por parte de los chicos victimizados en realidad reforzaba la victimización. Salmivalli y Helteenvuori (2007) encontraron que la agresión reactiva precedía a la victimización más que ser una consecuencia de la misma en chicos adolescentes de género masculino, no econtrando esta relación entre las chicas.

Por otro lado, la agresividad reactiva también podría ser una consecuencia de la constante victimización (Salmivalli y Helteenvuori, 2007). A pesar de que la agresión reactiva es a menudo vista como una reacción temperamental, esto no descarta la posibilidad de que factores externos, tales como la frustración constante del acoso que de forma reactiva provocaría reacciones agresivas (Berkowiltz, 1989). Por otra parte, la agresión reactiva se asocia con una tendencia a atribuir hostilidad hacia los demás (Dodge y Coie, 1987; Hubbard, Cillessen, Dodge, Coie, y Schwartz, 2001), y el rechazo real y el acoso de los compañeros puede ser 
asumido para fomentar una visión negativa de los compañeros (Salmivalli y Isaacs, 2005). Si este es el caso, la victimización debería predecir el aumento de la agresión reactiva. Desde el punto de vista de las consecuencias prácticas, esto sugeriría que la agresión reactiva de las víctimas podrían reducirse simplemente poniendo fin a la victimización (Salmivalli y Nieminen, 2002).

Vermande et al. (2007) llega a distinguir tres tipos de víctimas: la pasiva, la víctima agresiva reactiva y la víctima agresiva proactiva y reactiva. El segundo tipo coincidiría con lo que la investigación tradicionalmente ha nominado como víctima provocativa, mientras que el tercer grupo lo haría con la etiqueta de 'bully-víctima' (Salmivalli y Peets, 2009).

El aumento de nuestra comprensión sobre los tipos de víctimas agresivas es clave para el desarrollo de intervenciones eficaces, y una de las formas de conseguirlo es a través de las opiniones y experiencias de los niños y los adultos participantes de los escenarios donde el bullying se produce (Del Barrio et al ., 2003). Smith (1997) escribió que 'la investigación sobre el acoso escolar podría hacer un mayor uso de los métodos cualitativos y los estudio de caso: dado el volumen global estudios realizados, sabemos sorprendentemente poco sobre la dinámica relacional del acoso escolar' (p. 251).

Con estas premisas, el objetivo de esta investigación es distinguir tipos de víctimas agresivas, atendiendo a los testimonios del alumnado de Educación Secundaria.

\section{Método}

\section{Participantes}

Según Andréu (2001) el muestreo se orienta a la selección de aquellas unidades y dimensiones que garanticen mejor la cantidad (saturación) y la calidad (riqueza) de la información. En este caso hemos utilizado un muestreo intencional teórico (Singleton y Straits, 2004) para seleccionar los centros, intentando que la variación de contextos y muestras permitiera la comparación adecuada de los datos tal como puede verse en la Tabla 1 (principio de heterogeneidad; Valles, 1997).

Los participantes de esta investigación han sido 72 adolescentes (40 chicas y 32 chicos) escolarizados en cuatro centros de Educación Secundaria Obligatoria de Andalucía Occidental (rural/urbano; público/concertado) con diferentes roles dentro del aula (agresores, víctimas, delegados/mediadores, otros iguales), de edades comprendidas entre los 12 y los 16 años de edad y escolarizados en $2^{\circ}$, $3^{\circ}$ y $4^{\circ}$ de ESO.

Tabla 1. Selección de Centros educativos.

\begin{tabular}{lll}
\hline MEDIO TIPO CENTRO & Urbano & Rural \\
\hline Público & Dos grupos de discusión & Dos grupos de discusión \\
Concertado & Dos grupos de discusión & Un grupos de discusión \\
\hline
\end{tabular}




\section{Técnicas de evaluación}

En la presente investigación se ha aplicado una metodología cualitativa basada en la recogida de datos sistemática a través de dos técnicas de entrevista: la primera grupal denominada Focus Group o Grupo de Discusión, y la segunda individual, denominada entrevista en profundidad. Para los grupos de discusión se utilizó un guión de entrevista semiestructurado de 12 preguntas que exploraba los siguientes contenidos: bully, víctima, testigos, papel jugado por el profesorado, papel jugado por la familia y soluciones planteadas. El guión de las entrevistas en profundidad se centró en la dinámica social y relacional del bullying, explorando el proceso de victimización, los tipos de agresores, los tipos de víctimas y el papel jugado por otras personas (iguales, profesorado y padres) con un total de 10 preguntas.

Se llevaron a cabo siete grupos de discusión de ocho personas a partir de dos variables de selección (zona del centro y tipo de centro). Todos los grupos fueron mixtos en cuanto al sexo (hombre y mujer), curso $\left(2^{\circ}, 3^{\circ}\right.$ y $4^{\circ}$ de ESO) y perfiles en el aula (agresor, víctima, otros iguales). Con respecto a las entrevistas en profundidad, se realizaron un total de 16 (cuatro con agresores, cuatro con víctimas, cuatro con testigos y cuatro con mediadores escolares/delegados de clase de $2^{\circ}, 3^{\circ}$ y $4^{\circ}$ de ESO). En la Tabla 2 puede verse la composición de un grupo de discusión estándar.

Para garantizar el rigor y la validez de la investigación, de suma importancia en los estudios cualitativos (Relinque, Moral Arroyo, y González, 2013), se han utilizado cuatro medidas: en primer lugar, la triangulación intradatos también conocida como método comparativo constante (Strauss y Corbin, 1998) consistente en la comparación sistemática de las categorías y sus propiedades derivadas del análisis de los datos en distintos fragmentos de un mismo material, entre distintos materiales, entre distintos sujetos, en distintas situaciones $\mathrm{y}$ en distintos momentos para buscar regularidades o pautas que permitan definir una categoría, propiedad o relación derivada del análisis de datos como significativa.

En segundo lugar, la revisión de pares (Creswell y Miller, 2000) o triangulación interanalistas (Denzin, 1978), consistente en contrastar los resultados de la codificación de cada investigador descartando aquellos en los que no se lograra un acuerdo. En tercer lugar, controles de credibilidad o de las partes interesadas (Thomas, 2003): en cada centro educativo se ha realizado una sesión de devolución de los datos de la investigación, integrándose las aportaciones de

Tabla 2. Composición grupo de discusión estándar.

Composición Grupo de Discusión Estándar

\begin{tabular}{llll}
\hline Ocho participantes & Cuatro chicos & Dos alumnos $2^{\circ}$ ESO & Dos agresores \\
& & Un alumno $3^{\circ}$ ESO & Dos víctimas \\
& Un alumno $4^{\circ}$ ESO & Cuatro otros iguales \\
& Cuatro chicas & Dos alumnas $2^{\circ}$ ESO & Dos agresoras \\
& Una alumna $3^{\circ}$ ESO & Dos víctimas \\
& Una alumna $4^{\circ}$ ESO & Cuatro otros iguales \\
\hline
\end{tabular}


los participantes y utilizándolas como feedback en el proceso de construcción de teoría. Finalmente, la literatura técnica ha servido en la fase de escritura para extender, validar y refinar el conocimiento del objeto de estudio (triangulación teórica; Moral, 2006).

\section{Procedimiento}

Los cuatro centros participantes en el estudio habían colaborado anteriormente en diversos estudios de corte cuantitativo por lo que se aprovechó ese vínculo de colaboración para solicitar la participación en el estudio, siendo el director u orientador de estudio la persona de contacto en todos los casos. Los grupos de discusión fueron llevados a cabo en los propios Centros educativos y seleccionados y convocados a través de la figura del orientador psicopedagógico o responsable del Aula de Convivencia en el caso de existir, con el fin de conseguir los mejores informantes posibles y solicitar de una forma más ágil el consentimiento parental para la participación de los menores en la investigación.

Tan sólo se solicitó que en los grupos las variables sexo (hombre y mujer) y curso $\left(2^{\circ}, 3^{\circ}\right.$ y $4^{\circ}$ de ESO) estuviera distribuida por igual y que estuvieran presentes chicos que se hubieran vistos implicados en episodios de agresión entre iguales (como agresores, víctimas o testigos), según la experiencia del propio orientador en el trabajo con el alumnado del centro. En total se realizaron siete grupos de discusión distintos de una hora de duración, aprovechándose para ello las instalaciones facilitadas por cada uno de los centros y el espacio temporal del recreo más una clase. Su conducción corrió a cargo de una pareja de entrevistadores adultos previamente entrenada compuesta por un hombre y una mujer, ambos relacionados con el campo de la investigación en Ciencias Sociales y con experiencia en el desarrollo de este tipo de entrevistas.

Tras los primeros tres grupos comenzó a perfilarse la idea de entrevistar en profundidad a los protagonistas directos de la violencia escolar: agresores, víctimas, testigos y mediadores/delegados de clase (estos últimos aparecieron en los grupos de discusión como figuras importantes para comprender mejor la dinámica de la victimización en el aula). Solicitamos a dos de los centros (los que contaban con programas específicos de mediación y formación de mediadores) su consentimiento para esta nueva recogida de datos y se llevaron a cabo 16 entrevistas en profundidad de 30 minutos de duración, aprovechando el recreo de los menores. En este caso sólo un entrevistador se encargó de las entrevistas para facilitar la producción de discurso implicada en la entrevista en profundidad.

Se registraron todos los grupos de discusión y entrevistas en profundidad con una grabadora Olympus DS-75 lo que facilitó su posterior trascripción y análisis.

Análisis de datos

Para el proceso de análisis se ha seguido una adaptación del esquema propuesto por la Teoría Fundamentada (Grounded Theory) tal y como es propuesta por Strauss y Corbin (1998). Las fases del análisis se especifican a continuación: 
(1) Preparación de archivos de datos brutos: las respuestas de los participantes fueron transcritas e informatizadas para su tratamiento posterior con un programa computerizado de análisis de datos cualitativos (específicamente, el ATLAS.ti 5.0).

(2) Primer análisis de los datos en bruto: cada investigador identificó y definió fragmentos significativos del texto y los fue codificando de manera intuitiva, abierta y sin presupuestos teóricos prefijados (proceso de codificación abierta) teniendo en cuenta que los códigos 'agresor', 'víctima', 'testigo', 'familia', 'escuela', 'barrio-comunidad' y 'sociedad' habían sido introducidos en el diseño previamente siendo considerados como códigos teóricos deductivos. El proceso seguido inicialmente fue el la codificación línea a línea, usando para este proceso el ATLAS.ti 5.0 y dando prioridad a las expresiones y términos utilizados directamente por los participantes en el estudio (codificación in vivo).

(3) Desarrollo de las categorías iniciales (codificación axial): tras finalizar este proceso y como estrategia encaminada a la validez del estudio ambos investigadores contrastaron sus sistemas de categorías. Hubo un acuerdo sobre un total de 45 categorías, el $90 \%$ de las planteadas por ambos investigadores. A partir de estas categorías acordadas, ambos investigadores trabajaron conjuntamente leyendo de nuevo los datos para reducir y agrupar las categorías, buscando temas secundarios, propiedades de categorías principales y secundarias y eliminando categorías redundantes. Todo este proceso se fue registrando en notas teóricas o descriptivas que fueron integradas a la hora de crear el modelo resultante del análisis y en la escritura de los resultados.

(4) Creación de un modelo de categorías principales, secundarias y sus propiedades (codificación selectiva): en esta etapa las categorías, subcategorías, propiedades y relaciones entre las mismas que los analistas estaban de acuerdo en considerar como parte de un mismo esquema teórico se redujeron e integraron en redes conceptuales descriptivas o explicativas, es decir, utilizando el método de comparación constante se descartaron categorías o hipótesis sobre relaciones entre las mismas que pudimos anotar en la fase anterior al ver que solamente funcionaban en una situación determinada o carecían de poder explicativo suficiente

\section{Resultados}

A continuación presentaremos las percepciones y teorías que los adolescentes mantienen con respecto a las víctimas provocativas o agresivas. Se ilustrará la escritura de los resultados con algunos fragmentos literales significativos de los discursos adolescentes siendo la codificación de los mismos como sigue: GD (grupo de discusión)/EP (entrevista en profundidad) + número del grupo o entrevista $+\mathrm{A}$ (chica), $\mathrm{O}$ (chico) + número identificativos en el grupo de 
discusión/agr (agresor), vic (Víctima), test (testigo) o med (mediador) en las entrevistas en profundidad.

\section{Víctimas provocativas o agresivas}

Los resultados de este estudio permiten distinguir seis tipos de víctimas agresivas identificados por los adolescentes participantes en la investigación: víctimas agresivas por acumulación de estrés, provocativas, por contagio, pasivas delatoras, las víctimas de alto perfil académico protegidas por el profesorado, y por último, las víctimas agresivas por desplazamiento.

El primero de los tipos de víctimas se define como víctima agresiva por acumulación de estrés, un perfil que podríamos denominar 'de olla a presión', caracterizado por la agresión reactiva de la víctima que no aguanta más las burlas, insultos, golpes y otras manifestaciones abusivas por parte de sus compañeros. Siempre ha sido pasivo pero de repente se defiende reactivamente sin pedir ayuda a terceros (iguales o adultos).

GD3A4: hay chicos que siempre se meten con ellos y son callaítos y todo eso, e incluso les quitan el bocadillo o les pegan, y un día se hartan y de repente se ponen a pegarte o te chillan y la gente se ríe porque lo hacen como muy exagerado y nadie se lo esperaba.

En segundo lugar, emerge el concepto de víctima provocativa. Se trataría de chicos provocadores que son irritantes y contestatarios con sus compañeros y con los profesores (no dejan dar la clase en paz, insultan, mantienen discursos provocadores e interrumpen aunque siempre son ellos quienes salen perdiendo) y que son rechazados tanto por compañeros como por el profesorado al que molesta al dar clase y al que acude si le han pegado o insultado. El problema en este caso podría ser denominado como 'el cuento de Pedro y el lobo': el profesorado tiende a percibir la parte provocativa como la causante de la victimización, por lo que otros aspectos más pasivos de la victimización son menos atendidos.

GD2A7: No, es que es su forma de ser, a lo mejor lo hace sin querer, pero es que lo hace. El profesor está explicando y le pregunta, espérate que llegue, y el profesor está diciendo algo y va y se mete y: te quieres callar ya, y a lo mejor le dices algo y te dice que te calles gordo, te voy a mete un ostia', y me va a meter tres, y al final cuando le doy, 'Pom' va al director o al jefe de estudio y ahora dice que no tiene ganas de bajar, etc.

En tercer lugar, las víctimas por contagio, que se juntan con alguien violento y se 'contagian' volviéndose proactivas las agresiones. El chico o chica que cambia de Centro y 'empieza una nueva vida': ha sido victimizado en su Centro anterior y ahora se junta con chicos agresores para compensar su rol anterior. 
GD1A2: Sí, pues yo tengo uno en mi clase que ha venido de otro colegio y ahora también se hace con los otros y también, no tanto como los vagos de siempre, pero también se mete.

GD1A3: La gente que viene de otros colegios se suele juntar con la gente así que... típicos repetidores y todo eso, porque piensan que no les van a hacer lo mismo que les hacían en ese otro colegio.

GD1A 4: Pero depende de cómo se integren. A lo mejor se integran mal y a lo mejor les pasa el otro lado contrario, que se meten con ellos y les pasan esas cosas, depende, si tú vienes nuevo de un sitio y...el novato siempre...

En cuarto lugar, la víctima pasiva delatora que denuncia su situación ante un adulto es considerada como víctima agresiva. Para los adolescentes el hecho de que una víctima decida chivarse a un padre o un profesor es considerado como una agresión indirecta y desequilibrada (no se defiende directamente de su agresor y encima invoca a una figura punitiva que tiene mucho poder) de alguien que debería estar callado y no defenderse como dicta su etiqueta de víctima.

EP4Atest: 6: Joaquín se chivó a un profesor porque estaban en su patio y estaban fumando y le estaban echando las colillas y les dijo que no le echasen más y los niños tenían 15 o 16 y fueron a pegarle a la salida y todo. Y estuvo un curso entero saliendo una hora antes.

GD5A2: Lo peor que hay es ser un chivato.

GD7O3: Si ves que le están pegando, o yo que sé, no se lo puedes decir al profesor, porque eres un chivato.

En quinto lugar, las víctimas agresivas de alto perfil académico protegidas por el profesorado, es un subtipo que compartiría algunas características con la víctima agresiva anteriormente descrita y con el subtipo provocativo. En este caso, se trataría de algunos alumnos brillantes ('empollones'), que contarían con el apoyo y el cariño del profesorado (al contrario que las víctimas provocativas puras) pero que provocarían sutilmente a los compañeros usando sobre todo el plano del rendimiento académico y la inteligencia.

EP11Omed: 6: pero es que algunos se lo buscan, los niños que son unos empollones y encima hagan lo que hagan siempre tienen razón para el profesor y nunca tienen culpa de nada, y esos se pasan muchas veces y provocan a los demás pero dándoselas de listo y como que tú eres tonto... y luego van llorando al profesor.

En sexto lugar se encontrarían las víctimas por desplazamiento, de las que se podrían identificar dos subtipos. Un primer tipo es el de aquellas que desplazan las agresiones a otros contextos no escolares, en especial al contexto familiar. La frustración que genera el ser victimizado y no defenderse se relaciona con la posibilidad de pagarla con otros significativos 'que saben que no van a reaccionar igual': los padres y madres (violencia filio-parental) o un chivo expiatorio (que en algunos casos también es colocado dentro del subsistema familiar, como es el 
hermano o hermana menor, aunque también pude ser un compañero más pequeño).

GD3A4: yo conozco una niña que todo este Instituto le tenía manía pero sabiendo que a lo mejor paraban sin decirle nada, pasaban de ella, y ella se inventaba cosas o hacía algo y otra vez volvían todos, y entonces entró la hermana y le cogieron manía también a la hermana, por que todo lo que hacía ella le echa las culpas a su hermana.

Entrevistador: incluso puede ser que como le tienen manía a alguien de tu familia o a tu hermano y entonces llegas tú y te comes todo el marrón ese...

GD3A4: y muchas veces han intentado pegarle a esa niña y entonces ella ha dicho no es que yo no he sido ha sido mi hermana, no sé qué, para que la hermana cargara con las culpas.

Un segundo tipo de víctima agresiva por desplazamiento referido por el grupo hace referencia a los chicos y chicas bullies que agreden como víctimas agresivas, pero esta vez la victimización se produce en el contexto familiar y el desplazamiento se haría en el Centro hacia los compañeros. Es decir, podría considerarse a algunos agresores como víctimas en un microcontexto y agresores en otro.

GD4A3: yo conozco a uno de mi clase la que han expulsado al menos siete veces... no los conozco pero el mismo va diciendo que su madre le ha tirado un cuchillo que su madre le pegó con una zapatilla, y luego lo de su casa lo descarga con nosotros $[\ldots]$.

Entrevistador 2: es decir lo que le ocurre en su casa luego viene y lo descarga en el colegio.

GD4A3: es que con sus padres no lo puede pagar.

En la Figura 1 se resume los tipos de víctimas agresivas identificadas.

\section{Discusión y conclusiones}

El objetivo de esta investigación era distinguir tipos de víctimas agresivas, atendiendo a los testimonios del alumnado de Educación Secundaria.

En líneas generales podemos destacar que los resultados de este estudio van más allá de la propuesta de Vermande et al. (2007) según la cual se pueden distinguir al menos dos tipos de víctimas agresivas: la víctima agresiva reactiva y la agresiva proactiva y reactiva (o bully-víctima) proponiendo seis subtipos de víctimas agresivas: víctimas agresivas por acumulación de estrés, provocativas, por contagio, pasivas delatoras, de alto perfil académico protegidas por los profesores y por desplazamiento.

El primero de los tipos de víctimas, definido como víctima reactiva por acumulación de estrés, es coincidente con la definición de Salmivalli y Helteenvuori (2007), quienes sugirien que la agresividad reactiva también podría ser una consecuencia de la constante victimización. Es decir, más que 


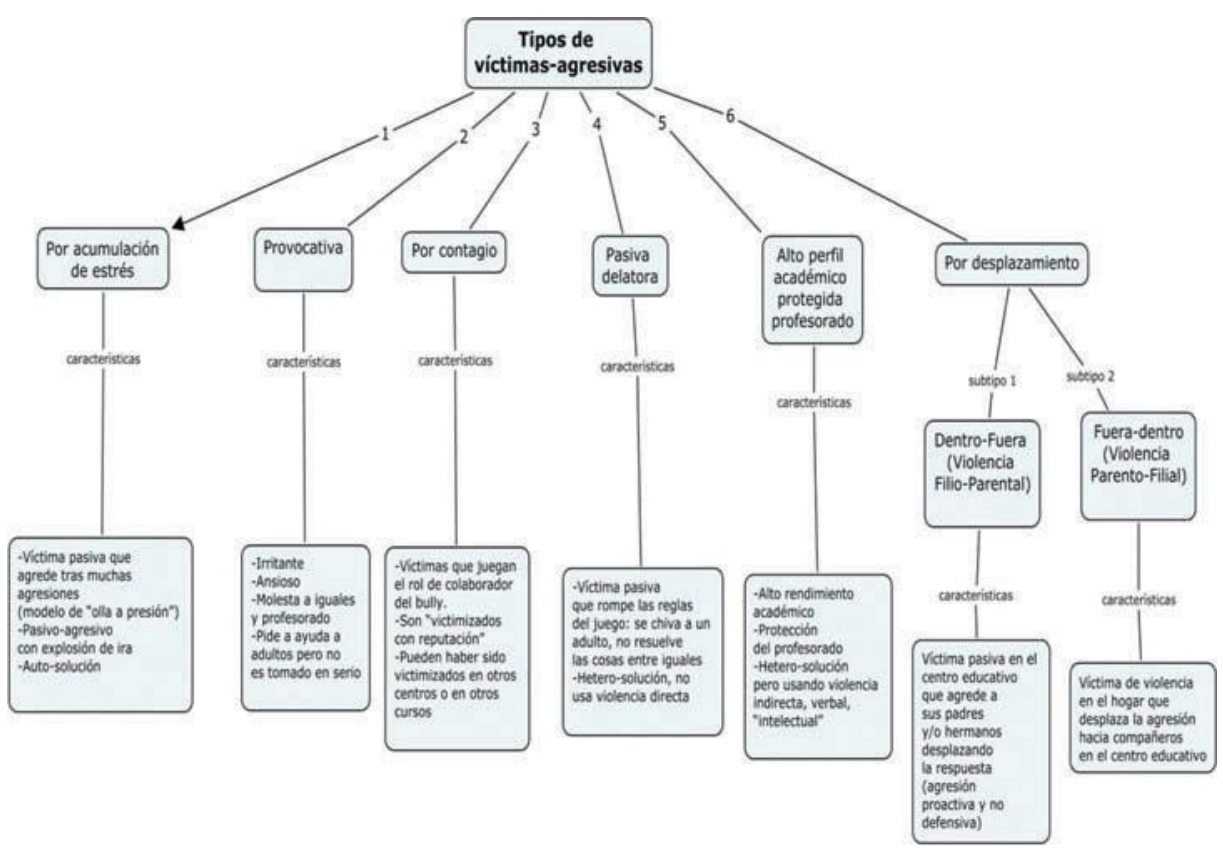

Figura 1. Subtipos de víctimas agresivas.

aspectos temperamentales como impulsividad, impaciencia o ansiedad, las causas que desencadenarían el paso de víctima pasiva a reactiva serían externos, tales como la frustración constante del acoso que de forma reactiva provocaría reacciones agresivas (Berkowitz, 1989).

Las consecuencias de estas reacciones defensivas son contradictorias. Por un lado, la investigación arroja resultados a favor de la relación entre la agresión reactiva y la victimización, por ejemplo, Salmivalli et al. (1996) indicaron que los preadolescentes identificaban el contraataque como una respuesta que era más probable que exacerbara la intimidación, por lo que buscar venganza o agredir reactivamente por parte de los chicos victimizados en realidad reforzaría la victimización (Kochenderfer-Ladd, 2004; Putallaz y Bierman, 2004). Sin embargo, entre las soluciones adolescentes dirigidas a las víctimas de acoso escolar se encuentra la estrategia individual positiva denominada 'espabilarse' (del Moral, Suárez, y Musitu, 2012): no callarse, defenderse física y verbalmente, no tener miedo, aguantar y que transmitan que no pueden con ellas. Es decir, por un lado defenderse puede aumentar la victimización pero según los adolescentes la víctima que empieza a 'espabilarse' deja de ser víctima en un sentido muy importante: la desigualdad de poder con el agresor va disminuyendo, por lo que pasarían a ser victimizados 'a secas' y dejarían de ser víctimas de bullying (Salmivalli y Peets, 2009).

El segundo tipo de víctima sería la víctima provocativa coincidente con las descripciones de Crick et al. (1999). Serían aspectos relacionados con la impulsividad, la ansiedad, la forma de ser y las habilidades de relación interpersonal las 
que caracterizarían a este tipo de víctima. Al contrario que otros tipos de víctimas los adolescentes encuentran justificadas estas agresiones, por lo que la propia definición de víctima pasaría a ser redimensionada. Es decir, para los adolescentes una víctima agresiva provocativa se merece lo que le pasa por su constante línea base de comportamiento molesto. Además, no encuentra apoyos ni en el mundo adulto ni en el de los iguales por lo que la soledad y la dificultad para buscar soluciones serían la norma en estos casos. $\mathrm{Si}$ a esto le añadimos que algunos autores han caracterizado a los hogares de las víctimas provocativas como punitivos, hostiles, con altos niveles de negligencia, sobreprotección (Bowers, Smith, y Binney, 1994) y rechazo (Veenstra et al., 2005), y con bajos niveles de seguimiento y calidez, podemos imaginar que las llamadas de atención para ser considerados, aceptados y queridos son infructuosas en los principales contextos de desarrollo.

En tercer lugar, las víctimas agresivas por contagio: se juntan con alguien violento y se 'contagia' agrediendo proactivamente. Hay un acuerdo generalizado en que la agresión proactiva se asocia con cualidades de liderazgo y popularidad en los grupos de iguales (Dodge y Coie, 1987; Prinstein y Cillessen, 2003) y que un chico ansioso y tímido que además tienen amigos débiles físicamente o rechazados por los otros, tiene peor pronóstico que otro chico de similares características con amigos fuertes o aceptados (Hodges, Malone, y Perry, 1997). Los resultados de nuestro estudio ofrecen una teoría adolescente de la interesante dinámica del paso de ser víctima pasiva a agresiva por contagio: el cambio de Centro o de nivel educativo supondría una oportunidad para dejar de ser victimizado o al menos para seguir siendo victimizado pero contando con un grupo de iguales fuertes. Este aspecto podría estar estrechamente relacionado con el rol de colaboradores del bully (del Moral et al ., 2012 ; Salmivalli, 2010), puesto que el cambio de este tercer tipo de víctima no consiste en convertirse en bully, sino más bien en colaborador de éste, por lo que ciertos aspectos de victimización provenientes del bully seguirían estando presentes en su vida, pero sin duda mucho más controlables, predecibles y aguantables.

En cuarto lugar, la víctima pasiva delatora, que es agresiva por incumplir el rol de la víctima pasiva (no defenderse, no pedir ayuda) sumado al uso de una estrategia de resolución de conflictos considerada como ilegítima en la cultura escolar adolescente: pedir ayuda a un adulto (profesor o padre). Las cosas de los adolescentes se resuelven entre adolescentes y no se 'empeora' la situación introduciendo en el conflicto a los adultos. Esta teoría la hemos obtenido en diversos centros y con una cierta unanimidad, no sólo por parte de agresores y testigos, sino también como explicación por parte de chicos victimizados del por qué no pidieron ayuda a sus padres y profesores (en uno de los centros una chica comentaba que 'peor que pegar a otro injustamente estaba ser un chivato'). Esta sanción social adolescente perjudica a las víctimas y a todos los testigos que podrían poner en marcha el proceso de solución denunciando la situación a un adulto además que dificulta los procesos de aprendizaje cooperativos que tan buenos resultados han demostrado a la hora de disminuir las agresiones indirectas (León, Gozalo, y Polo, 2012). 
Por otro lado, se han apuntado algunas ideas muy interesantes acerca de las víctimas agresivas por desplazamiento, que permiten poner en relación distintos tipos de violencia y distintos escenarios de desarrollo adolescente. En el caso de la violencia 'dentro-fuera' la hipótesis es la siguiente: la frustración acumulada en el contexto escolar se expresaría de forma violenta en el seno familiar, contra los padres o hermanos. Algunos autores han caracterizado a los hogares de las víctimas pasivas con un ambiente familiar más positivo que los bullies y las víctimas agresivas (Bowers et al., 1994). Podría hipotetizarse que las agresiones despazadas al hogar supondrían un intercambio violento en el caso de las víctimas agresivas y los bullies, generando situaciones bidireccionales de violencia (Ibabe, 2011) mientras que si una víctima pasiva de bullying comenzara a agredir en casa la violencia sería más unidireccional (de hijo a padres).

Este dato que relaciona la victmización por bullying y la violencia filioparental es novedoso y no es coincidente con las investigaciones previas que ponen de manifiesto la alta correlación entre ser bully en el contexto escolar y ser violento contra los padres (Ibabe, Jaureguizar, y Díaz, 2007; Sempere, Losa, Pérez, Esteve, y Cerdá, 2005).

Por último, el segundo subtipo de víctima por desplazamiento sería el de los chicos que agreden proactivamente en el contexto escolar pero son victimizados en sus hogares. En este caso ser víctima de malos tratos, de prácticas punitivas o estilos parentales autoritarios-violentos se relacionaría con una mayor probabilidad de ser violento en la escuela. Diversos autores han investigado esta cuestión llegando a la conclusión que en familias donde un menor ha sido maltratado, la violencia es percibida como un modo de descargar la rabia y la frustración, además de considerarla como una forma aceptable y preferencial de resolver conflictos (Jaffe, Wolfe, y Wilson, 1990; McCord, 1988). Estos autores consideran, además, que este hecho pudiera estar relacionado con la violencia en la escuela (Holt, Buckley, y Whelan, 2008; McCloskey y Lichter, 2003) o en futuras relaciones de pareja (Rossman, Hughes, y Rosenberg, 1999).

A la luz de estos resultados proponemos una distinción básica entre víctimas pasivas y víctimas agresivas, más que provocativas como consideran algunos autores, puesto que no todas ellas utilizan la provocación o presentan las características de impulsividad, impaciencia o ansiedad que caracterizan a las víctimas provocativas.

Las implicaciones para la práctica son muy importantes, en primer lugar por provenir estas teorías de las experiencias y conocimientos de los adolescentes y estar estrechamente vinculadas al contexto donde se produce el bullying. El solo hecho de pensar acerca de sus compañeros que están siendo victimizados supone ponerse en su lugar, intentar comprender profundamente por qué se encuentran viviendo una situación tan dolorosa y al mismo tiempo, tomar conciencia del papel jugado por cada adolescente en relación a la violencia escolar entre iguales. Por otro lado, conocer los tipos de víctimas agresivas puede suponer un gran avance para el diseño de actuaciones preventivas no sólo a nivel de centro educativo sino también a nivel de aula, como herramienta para educadores que se implican y observan a su alumnado intentando ayudarles en su desarrollo. El 
hecho de que pedir ayuda a los adultos sea sancionado socialmente en la cultura escolar adolescente no debería entrar en conflicto con planificar actuaciones o prestar ayuda estratégicamente. Conocer las características de cada tipo de víctima puede servir, por ejemplo, para trabajar con todo el grupo de colaboradores o asistentes del bully y explorar sus historias pasadas y presentes como víctimas para trabajar la empatía, o para explorar la situación familiar de las víctimas en busca de apoyos o incluso para ofrecer ayuda a los progenitores, o para trabajar a nivel del grupo clase el cuestionamiento de las normas implícitas a la hora de pedir ayuda.

Esta investigación con la que los investigadores han disfrutado enormemente no está exenta de puntos a mejorar. Por un lado, contar sólo con adolescentes de $2^{\circ}$ a $4^{\circ}$ de ESO deja fuera al alumnado de $1^{\circ}$ de ESO. Atendidendo a los resultados de este estudio habría sido interesante contar con este alumnado para evaluar la victimización en el momento del cambio de centro educativo. Por otro lado, a pesar de haber logrado el criterio de cantidad (saturación teórica) otros informantes podrían haber complementado los datos como son el profesorado o los padres.

\section{References / Referencias}

Andréu, J. (2001). Las técnicas de análisis de contenido: Una revisión actualizada. Documento de trabajo, S2001/03, Centro de estudios andaluces. Retrieved from http://public.centrodeestudiosandaluces.es/pdfs/S200103.pdf

Berkowitz, L. (1989). Frustration-aggression hypothesis: Examination and reformulation. Psychological Bulletin, 106, 59-73. doi:10.1037/0033-2909.106.1.59

Bowers, L., Smith, P. K., \& Binney, V. (1994). Perceived family relationships of bullies, victims and bully/victims in middle childhood. Journal of Social and Personal Relationships, 11, 215-232. doi:10.1177/0265407594112004

Buelga, S., Cava, M. J., \& Musitu, G. (2012). Reputación social, ajuste psicosocial y victimización entre adolescentes en el contexto escolar. Anales de Psicología, 28, 180187.

Camodeca, M., Goossens, F. A., Terwogt, M. M., \& Schuengel, C. (2002). Bullying and victimization among school-age children: Stability and links to proactive and reactive aggression. Social Development, 11, 332-345. doi:10.1111/1467-9507.00203

Cook, C. R., Williams, K. R., Guerra, N., Kim, T., \& Sadek, S. (2010). Predictors of bullying and victimization in childhood and adolescence: A meta analytic investigation. School Psychology Quarterly, 25, 65-83. doi:10.1037/a0020149

Creswell, J. W., \& Miller, D. L. (2000). Determining validity in qualitative inquiry. Theory into Practice, 39, 124-130. doi:10.1207/s15430421tip3903_2 
Crick, N. R., Grotpeter, J. K., \& Rockhill, C. (1999). Social information processing and children's loneliness. In K. Rotenberg \& S. Hymel (Eds.), Children's loneliness (pp. 153-175). New York, NY: Cambridge University Press.

Cuadrado, I., \& Fernández, I. (2009). ¿Son comportamientos residuales las conductas violentas de las víctimas agresivas en las escuelas? Predominio y predicción. Infancia y Aprendizaje, 32, 531-551. doi:10.1174/021037009789610386

Del Barrio, C., Martín, E., Montero, I., Gutiérrez, H., \& Ferníndez, I. (2003). La realidad del maltrato entre iguales en los centros de secundaria españoles. Infancia y Aprendizaje, 26, 25-47. doi:10.1174/02103700360536419

del Moral, G., Suárez, C., \& Musitu, G. (2012). Roles de los iguales y bullying en la escuela: Un estudio cualitativo. Revista de Psicología y Educación, 7, 105-127.

Denzin, N. (1978). The research act. A theoretical introduction to sociological methods. New York, NY: McGraw Hill.

Dodge, K. A., \& Coie, J. D. (1987). Social information-processing factors in reactive and proactive aggression in children's peer groups. Journal of Personality and Social Psychology, 53, 1146-1158. doi:10.1037/0022-3514.53.6.1146

Dodge, K. A., Lochman, J. E., Harnish, J. D., Bates, J. E., \& Pettit, G. S. (1997). Reactive and proactive aggression in school children and psychiatrically impaired chronically assaultive youth. Journal of Abnormal Psychology, 106, 37-51. doi:10.1037/0021-843X.106.1.37

Hodges, E. V. E., Malone, M. J., \& Perry, D. G. (1997). Individual risk and social risk as interacting determinants of victimization in the peer group. Developmental Psychology, 33, 1032-1039. doi:10.1037/0012-1649.33.6.1032

Holt, S., Buckley, H., \& Whelan, S. (2008). The impact of exposure to domestic violence on children and young people: A review of the literature. Child Abuse and Neglect, 8, 97-810.

Hubbard, J., Dodge, K., Cillessen, A., Coie, J., \& Schwartz, D. (2001). The dyadic nature of social information processing in boys' reactive and proactive aggression. Journal of Personality \& Social Psychology, 80, 268-280. doi:10.1037/00223514.80.2.268

Hunter, S. C., Mora-Merchan, J. A., \& Ortega, R. (2004). The long-term effects of coping strategy use in victims of bullying. The Spanish Journal of Psychology, 7, 3-12. doi:10.1017/S1138741600004704 
Ibabe, I. (2011). ¿Hasta qué punto la violencia filio-parental es bidireccional? Anales de Psicología, 27, 265-277.

Ibabe, I., Jaureguizar, J., \& Díaz, O. (2007). Violencia filio-parental: Conductas violentas de jóvenes hacia sus padres. Vitoria: Servicio Central de Publicaciones del Gobierno Vasco.

Jaffe, P. G., Wolfe, D. A., \& Wilson, S. K. (1990). Children of Battered Women. Beverly Hills, CA: Sage.

Kochenderfer-Ladd, B. (2004). Peer victimization: The role of emotions in adaptive and maladaptive coping. Social Development, 13, 329-349. doi:10.1111/j.14679507.2004.00271.x

León, B., Gozalo, M., \& Polo, M. I. (2012). Aprendizaje cooperativo y acoso entre iguales. Infancia y Aprendizaje, 35, 23-35. doi:10.1174/021037012798977494

McCloskey, L. A., \& Lichter, E. L. (2003). The contribution of marital violence to adolescent aggression across different relationships. Journal of Interpersonal Violence, 18, 390-412. doi:10.1177/0886260503251179

McCord, J. (1988). Parental aggressiveness and physical punishment in long-term perspective. In G. Hotaling, D. Finkelhor, J. Kirkpatrick \& M. Straus (Eds.), Family Abuse and its Consequences: New Directions in Research (pp. 91-98). Beverly Hills, CA: Sage.

Moral, C. (2006). Criterios de validez en la investigación cualitativa actual. Revista de Investigación Educativa, 24, 147-164.

Olweus, D. (1978). Aggression in the schools: Bullies and whipping boys. Washington, DC: Hemisphere.

Olweus, D. (1993). Bullying at school: What we know and what we can do. Oxford: Blackwell.

Ortega, R., \& del Rey, R. (2008). La víctima de maltrato y acoso entre compañeros. In M. Herrera (Coord.), Hostigamiento y hábitat social: Una perspectiva victimológica (pp. 209-236). Granada: Comares.

Perry, D. G., Kusel, S. J., \& Perry, L. C. (1988). Victims of peer aggression. Developmental Psychology, 24, 807-814. doi:10.1037/0012-1649.24.6.807

Poulin, F., \& Boivin, M. (2000). Reactive and proactive aggression: Evidence of a twofactor model. Psychological Assessment, 12, 115-122. doi:10.1037/10403590.12.2.115 
Prinstein, M. J., \& Cillessen, A. H. N. (2003). Forms and functions of adolescent peer aggression associated with high levels of peer status. Merrill-Palmer Quarterly, 49, 310-342. doi:10.1353/mpq.2003.0015

Putallaz, M., \& Bierman, K. L. (2004). Aggression, antisocial behavior and violence among girls. New York, NY: Guilford Press.

Relinque, C., Moral Arroyo, G., \& González, M. T. (2013). Consejos prácticos para escribir un artículo cualitativo publicable en Psicología. Psychosocial Intervention, 22, 71-79. doi:10.5093/in2013a9

Rossman, R. B. B., Hughes, H. M., \& Rosenberg, M. S. (1999). Children and interparental violence. Philadelphia, PA: Brunner/Mazel.

Salmivalli, C., \& Helteenvuori, T. (2007). Reactive, but not proactive aggression predicts victimization among boys. Aggressive Behavior, 33, 198-206.

doi:10.1002/ab.20210

Salmivalli, C., \& Isaacs, J. (2005). Prospective relations among victimization, rejection, friendlessness, and children's self- and peer-perceptions. Child Development, 76, 1161-1171. doi:10.1111/j.1467-8624.2005.00841.x-i1

Salmivalli, C., \& Nieminen, E. (2002). Proactive and reactive aggression among school bullies, victims, and bully-victims. Aggressive Behavior, 28, 30-44. doi:10.1002/ ab.90004

Salmivalli, C., \& Peets, K. (2009). Bullies, victims, and bully-victim relationships. In K. Rubin, W. Bukowski, \& B. Laursen (Eds.), Handbook of peer interactions, relationships, and groups (pp. 322-340). New York, NY: Guilford Press.

Salmivalli, C. (2010). Bullying and the peer group: A review. Aggression and Violent Behavior, 15, 112-120. doi:10.1016/j.avb.2009.08.007

Salmivalli, C., Lagerspetz, K., Björkqvist, K., Österman, K., \& Kaukiainen, A. (1998). Bullying as a group process: Participant roles and their relations to social status within the group. Aggressive Behavior, 22, 1-15. doi:10.1002/(SICI)1098-2337(1996) $22: 1<1:: A I D-A B 1>3.0 . C O ; 2-\mathrm{T}$

Schäfer, M., Werner, N. E., \& Crick, N. R. (2002). A comparison of two approaches to the study of negative peer treatment: General victimization and bully/victim problems among German school children. British Journal of Developmental Psychology, 20, 281-306. doi:10.1348/026151002166451

Schwartz, D. (2000). Subtypes of victims and aggressors in children's peer groups. Journal of Abnormal Child Psychology, 28, 181-192. doi:10.1023/A:1005174831561 
Schwartz, D., Dodge, K. A., Coie, J. D., Hubbard, J. A., Cillessen, A. H. N., Lemerise, E. A., ... Bateman, H. (1998). Socialcognitive and behavioral correlates of aggression and victimization in boys' play groups. Journal of Abnormal Child Psychology, 26, 431-440. doi:10.1023/A:1022695601088

Schwartz, D., Proctor, L. J., \& Chien, D. H. (2001). The aggressive victim of bullying: Emotional and behavioural dysregulation as a pathway to victimization by peers. In J. Juvonen \& S. Graham (Eds.), Peer harassment in school: The plight of the vulnerable and victimized (pp. 147-174). New York, NY: Guilford Press.

Sempere, M., Losa, B., Pérez, M., Esteve, G., \& Cerdá, M. (2005). Estudio cualitativo de menores y jóvenes con medidas de internamiento por delitos de violencia intrafamiliar. Barcelona: Àmbit social i criminològic. Centre D’Estudis Jurídics i Formació Especialitzada. Departament de Justícia. Generalitat de Catalunya.

Singleton, R. A., \& Straits, B. C. (2004). Approaches to Social Research. New York, NY: Oxford

University Press. Smith, P. K. (1997). Commentary III. Bullying in life-span perspective: What can studies of school bullying and workplace bullying learn from each other? Journal of Community \& Applied Social Psychology, 7, 249-255. doi:10.1002/(SICI)1099- 1298(199706)7:3<249::AID-CASP425>3.0.CO;2-2

Strauss, A., \& Corbin, J. (1998). Basics of qualitative research: Techniques and procedures for developing grounded theory (2nd ed.). Thousand Oaks, CA: SAGE Publications.

Thomas, D. R. (2003). A general inductive approach for qualitative data analysis. Retrieved from http://www.health.auckland.ac.nz/hrmas/resources/qualdatanalysis. html\#Purposes Valles, M. S. (1997). Técnicas cualitativas de investigación social: Reflexión metodológica y práctica profesional. Madrid: Síntesis.

Veenstra, R., Lindenberg, S., Oldehinkel, A., De Winter, A., Verhulst, F., \& Ormel, J. (2005). Bullying and victimization in elementary schools: A comparison of bullies, victims, bully/victims, and uninvolved preadolescents. Developmental Psychology, 41, 672-682. doi:10.1037/0012-1649.41.4.672

Vermande, M. M., Olthof, T., Aleva, A. E., de Castro, O., Meulen, B., van der, M. A., \& Goossens, F. (2007, June). Victims of bullying in schools: Theoretical and empirical indicators for the existence of three categories. Presentation in Onderwijs Research Dagen, Groningen, The Netherlands. 